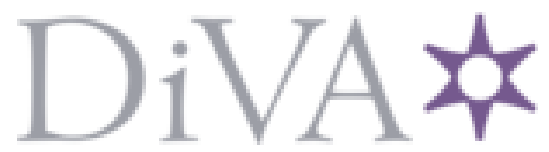

http://www.diva-portal.org

\title{
Postprint
}

This is the accepted version of a paper published in Digital Creativity. This paper has been peerreviewed but does not include the final publisher proof-corrections or journal pagination.

Citation for the original published paper (version of record):

Orrghen, A. (2017)

Surveying the literature on technoscience art: from pioneer stories to collaborations between artists, scientists and engineers as the object of study.

Digital Creativity, 28(2): 157-176

https://doi.org/10.1080/14626268.2017.1322986

Access to the published version may require subscription.

N.B. When citing this work, cite the original published paper.

Permanent link to this version:

http://urn.kb.se/resolve?urn=urn:nbn:se:uu:diva-321647 


\section{Surveying the Literature on Technoscience Art: From Pioneer Stories to Collaborations Between Artists, Scientists and Engineers as the Object of Study}

Abstract:

The aim of this article is to describe, analyse and categorize the literature on technoscience art in general and technoscience art collaborations in particular. I argue that the literature could be characterized by three thematic traditions: pioneer stories, writing aiming at mapping and categorizing, as well as those problematizing and contextualizing the field. Given that earlier research on technoscience art collaborations primarily consists of art historical and ethnographic studies, I further discuss the relation between these approaches and intend to provide a connection between them. Whereas art historical studies are more concerned with issues concerning art history as a discipline, ethnographic studies tend to be more concerned with challenges faced by interdisciplinarity. Finally, I discuss the role of artistic research and art practice in future studies on the topic and emphasize the understanding of technoscience art collaborations as an interdisciplinary effort.

Keywords:

Technoscience; technoscience art; art, science and technology; artist in residence; collaboration; historiography; artistic research; interdisciplinarity; art history; ethnography; anthropology; knowledge making; STS 


\section{Introduction}

In a 1987 issue of the international journal dedicated to the arts, sciences and technology

Leonardo, the art theorist Frank Popper introduces the term 'technoscience art'. Popper uses the term to define a new type of technological and scientifically oriented art that according to him has started to develop since the 1980s. Popper claims that the artists involved 'must have a strong interest in up-to-date scientific methods and discoveries and/or their technological applications' and he continues, 'this interest must be combined with both an aesthetic imagination and a will to create and communicate' (Popper 1987, 302). The art historian Ingeborg Reichle pays attention to Popper's introduction of the term and argues that technoscience art foregrounds 'technoscience' (Reichle 2009, 6). ${ }^{1}$

The concept 'technoscience', presented by among others Bruno Latour and Donna Haraway, refers to the technologization of science that has taken place throughout the 20th century. Today, Latour argues that science and technology are intertwined to such an extent they are inseparable in the process of knowledge making (e.g. Latour 1993). Latour's definition of technoscience refers to his understanding of science as the activity of making science instead of a scientific definition of science, and includes 'all the elements tied to the scientific contents no matter how dirty, unexpected or foreign they seem' (Latour [1987] 1999, 174). Haraway emphasizes this changing epistemological terrain and uses technoscience to signify 'a mutation in historical narrative' (Haraway 1997, 3).

The implication for technoscience art is a matter of debate about art as knowledge making or not. This is particularly pertinent in discussions concerning the role of artistic research (da Costa and Philips 2008; Gere 2010; Ascott 2011; Beloff, Berger and Haapoja 2011; Biggs and Karlsson 2011; Smite, Kluitenberg and Smits 2013; Smite, Medosch and Smits 2014; Salter 2015; Smite, Smits and Medosch 2016).

In his definition of technoscience art, Popper does not, however, pay attention to art as knowledge production, but focuses on the artists' explicit knowledge of scientific 
developments and their technological applications as well as conscious aesthetical investigation of its implications upon society. He excludes artists whom he refers to using technoscience 'only as a tool' (Popper 1987, 302). This means that Popper, contrary to Latour and Haraway, does not approach science and technology as inseparable in knowledge making. He further makes a distinction between a conscious or unconscious involvement with science and technology. This definition leads Popper to an exclusion of the scientifically and technologically oriented artists during the 1960s and 1970s, who he argues lack an 'awareness of the extent of social and cultural change produced by the latest technological developments' (Popper 1987, 302). In an interview in $C A A$ Art Journal from 2004 Popper, although aware that a number of scholars today understand technoscience as described in the previous paragraph, defends his standpoint by describing what he understands as a difference between theory and practice (Nechvatal 2004). ${ }^{2}$

In this article, I take a wider approach towards the concept of technoscience art. By using the concept of technoscience as understood by Latour and Haraway, my understanding of technoscience art, contrary to what is suggested by Popper, includes all the elements related to the scientific content. Hence, I thus understand technoscience art as an overall term referring to art that in one way or another interprets, investigates or uses technoscience. ${ }^{3}$ This implies a perspective that is less concerned with category making than practice and means that I, contrary to Popper, do include the scientifically and technologically oriented artists during the 1960s and 1970s. This use of the concept allows me, as has been pointed out by the historian of science Steven Shapin, to focus on the knowledge produced within technoscience as well as its artifacts (Shapin 2008, 3).

Due to the considerable amount of complex technology and science involved in technoscience art, I argue that technoscience art is characterized by creative processes that more or less demand interdisciplinary collaborations between artists, scientists and engineers (Candy and Edmonds 2002, 42; 2011, 8). The art historian Marga Bijvoet $(1997,4)$ even implies that interdisciplinary collaborations between artists, scientists and engineers were the most distinctive 
trait among the technically oriented artists who came forward during the 1960s. And recently, several scholars have paid attention to what they consider an increasing number of interdisciplinary collaborations in contemporary art (e.g. Steinheider \& Legrady 2004; Shanken 2005; Edmonds et al 2005; Reichle 2009).

These kinds of interdisciplinary collaborations between artists and technoscientists have been paid attention to in a number of ethnographic studies (e.g. Leach 2005; Fourmentraux 2006; Chan, Gonsalves and Metcalfe 2011; Born and Barry 2013; Krauß 2015). From an art historical perspective, these collaborations are, nonetheless, still underinvestigated. And the few art historians following Popper, who lately have started to take an interest in technoscience art, are highly aware of the fact that existing art historical research has not presented satisfying approaches to be able to understand and learn from these collaborations (e.g. Zwijnenberg 2009; Shanken [2007] 2010; Reichle 2009).

Which are then the approaches presented by existing research? And, what is the relation between art historical and ethnographic studies of technoscience art? The aim of this article is to describe, analyse and categorize the literature on technoscience art. Methodologically, I will do this by surveying the literature, including journals, exhibition catalogues, conference proceedings, anthologies and monographs. Firstly, I will pay attention to the authors and who they are, what questions have - or have not - been addressed, as well as emergent topics within the literature. Given my argument that technoscience art is characterized by interdisciplinary collaborations between artists, scientists and engineers, I will, secondly, describe and analyse the rhetoric of the collaborations. I thereby intend to complement earlier research by providing a link between ethnographic studies of technoscience art and histories of technoscience art. Due to its relation to technoscience art, I will, finally, discuss the role of artistic research in future studies on the topic.

'Indeed, there is no scientific/technological history of art', states the art historian Edward A. Shanken ([2007] 2010, 45) in an essay in which he makes a call for historiographical 
analyses of writing about art, science and technology. ${ }^{4}$ This article is not the comprehensive scientific/technological history of art Shanken asks for. However, its focus on technoscience art in general and collaborations between artists, scientists and engineers in particular, does strive to make it a contribution to one aspect of such a history.

\section{A brief history of collaborations within technoscience art}

When Bell Telephone Laboratories employees engineers Billy Klüver and Fred Waldhauer, and the artists Robert Rauschenberg and Robert Whitman founded the Experiments in Art and Technology (EAT) in 1966, they 'assumed the responsibility of developing an effective collaborative relationship between artists and engineers' (Klüver and Rauschenberg [1967] 2009). This supportive approach towards collaborations was part of an ongoing development in which artist centres, networks and artists in residencies emerged within the industry and the universities. For instance, corporate industries such as IBM and earlier mentioned Bell Labs hosted artists in residences, and in 1967 the artist Gyorgy Kepes founded the Center for Advanced Visual Studies (CAVS) at the Massachusetts Institute of Technology.

These efforts to support collaborative work between artists, engineers and scientists during the 1960s and 1970s illustrate what Michael Century (1999) characterizes as the first of three phases in the institutional development of the studio laboratory. Century uses studio laboratory to signify a hybrid environment where new media technologies are used for artistic production. Towards the end of the 1960s and in the early 1970s, the interest in collaborations between artists and the industry declined (Shanken 2005, 417). This did, nevertheless, entail that collaborations ended. They did, however, take place through less institutional and more informal contacts (Bijvoet 1997, 53). This is in particular illustrated by the history of computer art. For instance, in the UK there were no corporate companies like IBM or Bell Labs that supported computer art (Gere 2012,118). Instead, the development of the polytechnics played a major part in fostering computer art in the UK (Mason 2008). The universities also played an important part 
in the development of computer art in several other countries. ${ }^{5}$ These collaborations were, however, not systematically organized.

During the 1980s and 1990s, a second phase emerged as a more publicly oriented type of media centres started to appear, for example, Zentrum für Kunst und Medientechnologie (ZKM) in Karlsruhe, and a third phase started during the 1990s and is characterized by explicitly designed linkages between art, research and innovation. A key example is Xerox PARC artist-inresidence (PAIR) program. The programme brought together artists and researchers working with new media with the overall aim to investigate how they could mutually benefit from collaborating in a setting like PARC.

Century ends his report by paying attention to an emerging interest in biomedical matters among artists, suggesting that 'it is worth underlining the potential contribution to public discourse about scientific and technological issues' (Century 1999, 43). In a publication ten years later, the art historian Robert Zwijnenberg (2009) notices an increased interest from artists to participate in scientific practices, and shows that exchange projects such as artists in labs have become common. In 1996 the Wellcome Trust in the UK launched its first 'sciart' programme with the explicit intention to bridge art and science (Turney 2006; Webster 2006; Born and Barry 2013). This coincides with the establishment of artistic research over the last decade. Thus, further, albeit not exhaustive, examples of academic institutions fostering technoscience collaborations are the Swiss exchange programme Artists-in-labs (Scott 2006, 2010), the Master's programme in Arts, Computation and Engineering (ACE) at University of California Irvine (Born and Barry 2013), the Design Interaction Group at Royal College of Art (Miller 2014, 111113), the Planetary Collegium at Plymouth University (Candy and Edmonds 2011, 9), SymbioticA at the University of Western Australia (Catts and Bunt 2001) and Creation and Cognition Studios at the University of Technology Sydney (Edmonds et al 2005). ${ }^{6}$

Furthermore, Zwijnenberg implies that today art arguably turns the complicated questions and results of science into visual presentations in a way that makes them work as an 
intermediary link between science and the humanities, and alternatively between science and the public. Though not explicitly referring to Century, Zwijnenberg does indeed confirm his assumptions. ${ }^{7}$

Alongside this development a number of festivals, exhibitions and conferences have been launched. The professional organization for people who work with computer generated images, SIGGRAPH, held its first conference in 1973, in 1979 the first Ars Electronica festival was organized and in 1988 the International Symposium on Electronic Art (ISEA) kept its inaugural symposium. As annual events gathering artists, scientists and engineers these conferences do not only serve as important meeting places for discussing the state of the art within the field, but they are also important contributions to shed light upon its existence by conference proceedings as well as initiating databases and digital archives (Brown and Cunningham 2007; Manovich 2003; Schöpf 2004). However, as the art historian Oliver Grau has pointed out, this art is still at 'the periphery of the discipline of art history' (2007b, 8). Hence, in 2005 the first international conference on Media Art Histories was organized. This biannual event aims at discussing the history of media art "within the interdisciplinary and intercultural contexts of histories of art' (Grau 2007b, 1).

\section{Surveying the Literature of Technoscience Art: Three Thematic Traditions}

On an overall level, the literature on technoscience art can be divided into three thematic traditions. The first one consists of pioneer stories written by artists, engineers and scientists participating in collaborations. The second tradition consists of contributions by artists, scientists and art and media scholars, and attempts to map and categorize technoscience art. The third one, on the other hand, offers a shift in perspective since it consists of publications written mainly by art historians and anthropologists raising questions of how to understand and learn from technoscience art. $^{8}$ 


\subsection{Tradition One: Pioneer Stories}

The pioneer stories are either institutional stories by organizations and institutions fostering interdisciplinary collaborations, or individual stories about the making of particular art works. Key examples of the former are the publications by Billy Klüver describing the activities of EAT (e.g. EAT [1967] 2003; Klüver [1967] 2009; Klüver and Rauschenberg [1967] 2009, Klüver [1972] 2003). ${ }^{9}$ Alongside the institutional development of the studio laboratory a number of anthologies documenting the activities of the organizations have been published. These mostly do contain contributions in which the head of the organization describes the aim of the programme, while the participating artists, engineers and scientists describe their participation, and invited scholars place the organization in a broader context of similar activities. Art and Innovation: The Xerox Parc Artist-in-residence program, edited by Craig Harris (1999a) is a key example. ${ }^{10}$

Before continuing to the individual stories, I would like to pay attention to an emergent change in rhetoric of why the collaborative efforts have been encouraged. For example, in a 1967 article in EAT News Klüver and Rauschenberg state that: 'The purpose of Experiments in Art and Technology, Inc. is to catalyze the inevitable active involvement of industry, technology, and the arts' (Klüver and Rauschenberg [1967] 2009, 267). In an article almost forty years later, Dana Plautz, the head of IAEC, states: 'There is value to the collaboration between artists and technologists' $(2005,303)$, and continues: 'They [artists] can help bring research ideas to the public more quickly and communicate these ideas to a broad audience' (Plautz 2005, 303). Although both texts are written by organizations supporting a mutual exchange between the arts and the industry, set side by side, however, a noticeable difference in the role of the arts does appear. Both excerpts contain an 'agent' that will act in the favour of facilitating a relationship. The identities of the agent as well as the relationship to be supported do, nevertheless, differ. In the excerpt from 1967, the arts might be claimed to represent an end in itself, whereas in the one from 2005, the arts represent a means to an end. 
How is this change in rhetoric to be understood? One way to approach the shift is in the light of an increased complexity of science. From such a perspective, it has been argued that art works as an intermediary link between science and the public (Gerber 2006; Plautz 2005; Schlick 2005; Reichle 2009; Webster 2006; Wilson 2010, Scott 2010. Andrea Glauser, on the other hand, makes subtle distinctions into what she conceives as a too simplistic interpretation of a more complex phenomenon, by and large mainly claimed by organizations fostering collaborative efforts (Glauser 2010, 19).

Yet another way to understand the change in rhetoric might be at the backdrop of a general trend in the society ascribed to what is referred to as 'new public management'. Applied to the arts, such an interpretation implies that the arts are explicitly supposed to contribute to society in a more efficient and measurable way (see for instance Belfiore 2004). Klüver and Rauschenberg did, indeed, also call attention to that EAT would 'lead to new possibilities which will benefit the society' ([1967] 2009, 268). And, as Anne Collins Goodyear (2004, 628) has discussed, a number of collaborations supported by EAT led to engineering breakthrough and new inventions. That was, however, rather a result of, than the means of the collaboration.

Finally, this change in rhetoric might also be understood in relation to a wider historical context of the IT industry and its funding for experimental collaborations. ${ }^{11}$ In a report on future support systems for technology-based art, Michael Naimark ([2003] 2004) pays attention to the shift taking place, due to the dot com crash in the early 2000s.

The rhetoric of the individual stories has, on the other hand, not changed to the same extent. These are written by artists, scientists and engineers and provide us with glimpses of important tacit knowledge of collaborations. In describing their work, attention is paid above all to questions concerning how the artwork is created: 'Together we developed Emergence, a realtime 3D software system that supports an active responsive, networked, virtual world' (Allen 2005, 314); the kind of technology used: 'In our work we have used various minicomputers and graphics peripherals' (Bertók and Jankovic 1986, 27); how it works: 'My piece begins with an 
authentic tennis game with rackets wired for transmission of sound. The sound of the game will control the lights' (E.A.T. 1966 [2003], 221); as well as the impact of the work on the participating artist, engineer and scientist: 'My presence did not change the way molecular biologists go about their work, but it can be seen as a significant widening of horizons' (Hostettler 2010, 136). Except from being part of the anthologies, the individual stories are also to be found in publications in relation to festivals, conferences and exhibitions, as well as in journals, in particular Leonardo. ${ }^{12}$

\subsection{Tradition Two: Mapping and Categorizing}

Who are the artists? In what way are they using science and technology? Which are the art works created? Which are the exhibitions? Which are the organizations fostering this art? These are the major questions addressed by the second tradition. Based on articles, essays, interviews, exhibition catalogues, earlier writings, oral and written statements by artists, engineers and scientists, and other documents, these publications are mainly written by artists, engineers, scientists and art and media scholars and aim at mapping and categorizing technoscience art. The artist Douglas Davis' Art and the Future: A History/Prophecy of the Collaboration Between Science, Technology and Art from 1973 is an early example. Davis traces and describes how technology has been adopted, investigated and used by artists during the 20th century (Davis 1973). In 2002, the artist Stephen Wilson published his extensively covered exposé Information Art: Intersections of Art, Science, and Technology, which is one of many similar books published during the last decade. In roughly 900 pages, he maps and describes artists and art works labelled as information art (Wilson 2002). Further examples are many publications by Frank Popper such as Origins and Development of Kinetic Art (1968), Art of the Electronic Age (1993), From Technological to Virtual Art (2007); Computer Graphics: Computer Art by Herbert W. Franke (1971); Art of the Digital Age by Bruce Wands (2006); Signs of Life: Bio Art and Beyond by Eduardo Kac (2007); Shanken's Art and Electronic Media (2009); Wilson's Art + Science Now: How Scientific Research and Technological Innovation 
are Becoming Key to 21st-Century Aesthetics (2010); as well as a number of articles: Rachel Greene's 'Web Work: A History of Internet Art' (2000); Popper's 'Technoscience Art: The Next Step' (1987); Herbert W. Franke’s 'Computers and Visual Art' (1971); and Frank Dietrich's 'Visual Intelligence: The First Decade of Computer Art' (1986), to name but a few (see also Penny 2010, 2013; Orrghen 2015a). Put together, these publications provide an extensive calendar of technoscience art.

Designed almost like richly illustrated encyclopaedias and voluminous regarding the amount of information presented as well as the number of pages, the publications could indeed be considered as mere presentations of a field. However, these publications are not only mapping technoscience art, but they are also important contributions to the formation of it as a field. Two elements are particularly significant in this process. Firstly, the authors refer by and large to the same events, art works, artists and organizations. Secondly, they refer extensively to each other. Shanken's Art and Electronic Media is an illustrative example, since the book aside from referring to, for example Popper, Wilson and Davis, that is, literature written within the same tradition, also contains texts found within the first tradition. ${ }^{13}$ By repeating, cross referring to each other and reproducing earlier published texts, the publications contribute to the creation of a canon of technoscience art; which they themselves furthermore become a part of. This process is similar to the process Latour refers to as 'the context of citation' and describes how the use of references to other scientific texts acts as a way of strengthening the claims of a text (Latour [1987] 1999, 3340).

Furthermore, phrases such as ‘historic transformation' (Popper 2007, 4), 'radical development' (Popper 1993, 158), 'radically new' (Wands 2006, 14), 'an entirely new era in art' (Popper, 1993, 175), 'new art trend' (Wands 2006, 301), 'a new art' (Wilson 2010, 6) and 'entirely new possibilities' (Paul [2003] 2008, 7), preferably used in the introductory and concluding chapters, also contribute to the publications being considered not only as mere presentations. On 
the contrary, by contributing to an emergent rhetoric of newness and change, these publications are indeed part of constituting the field.

But, what is actually claimed to be new? And, in relation to what is it new?

According to the authors, the current technological and scientific development is suggested as a main reason for this change. This is, furthermore, particularly evident in the concepts used to characterize the art. A significant feature is that the art is often characterized by using umbrella terms in which the word 'art' is preceded by a scientific or technological term such as 'computer art', 'information art', 'technological art', 'electronic art', 'virtual art', 'bio art', 'digital art', 'internet art' and 'technoscience art'. This is indeed reflected in the titles. The art concerned is described as new in relation to previous art, and, among other things, the changes addressed concern altered creative tools, aesthetic issues, content, as well as relationship with the audience. For instance, Wands claims that ' $\mathrm{t}]$ he computer has enabled artists to create works, and new types of work, never before possible: intricate installations that could not be created by hand; sculptures formed in three-dimensional databases rather than in stone or metal' (2006, 8, my italic), and concerning interaction between the art work and the audience, Popper asserts that it is 'a process that becomes possible only through the new technological devices that create a situation in which questions by the user/spectator are effectively answered by the art work itself (1993, 8, my italic). The excerpts further illustrate that the development is not only referred to as new. Equally important seems to be to describe it as better than its predecessors. Hence, an underlying idea of progression appears.

Altogether, it becomes quite clear that mapping artists and art works is a recurrent feature parallel to technological and scientific changes approached within the art world. Lev Manovich (2003) suggests a similar interpretation. While discussing the history of new media, he particularly pays attention to the historical parallelism that exists between modern art and computing technology. An illustrative example could be found in Popper's books. While 
published within recurrent intervals, he addresses similar questions, but in relation to the latest technology and science used by artists.

Despite the emphasis on newness and change, questions concerning historical continuity have, however, not been addressed to any larger extent.

\subsection{Tradition Three: Problematizing and Contextualizing}

During the last ten years a few art historians have paid attention to that so far technoscience art has been disregarded or misinterpreted within history of art (see for instance Grau 2007a; Brown et al. 2008; Mason 2008; Shanken 2008; Higgins and Kahn 2012; Taylor 2014). Combined with an increased significance of technoscience art within our culture, they argue for a shift in focus towards a more historical approach. It is possible to regard the call as a response to the rhetoric of newness and change within the second tradition. Since as Grau points out, 'by focusing on recent art against the backdrop of historic developments, it is possible to better analyse which aspects are new and which aspects inherited in media art' $(2007 \mathrm{~b}, 8)$.

How then, is it possible to achieve such a shift? Two answers are particularly salient: One stresses the importance of understanding the historical and institutional conditions of technoscience art; another makes inquiries about analytical methods to approach it. A lion's share of these publications stems from the network of scholars participating in the emerging field Media Art Histories (for conference proceedings, see e.g. Broeckmann and Nadarajan 2008; Shanken 2008; Fritz 2008; Fernández 2008; Collins Goodyear 2008; Cubitt and Thomas 2013).

Scholars dealing with the historical and institutional conditions take particular interest in the importance of the place where the collaboration is carried out. Computer centres at universities and research departments at large industries and research laboratories are put to the fore as vital places for the migration of knowledge between artistic and scientific disciplines. As is revealed by a sample of the titles, White Heat Cold Logic: British Computer Art 1960-1980 (Brown et al. 2008), A Computer in the Art Room: The Origins of British Computer Arts 1950-1980 
(Mason 2008), Synthetics: Aspects of Art and Technology in Australia, 1956-1975 (Jones 2011) and A

Little Known Story about a Movement, a Magazine, and the Computer's Arrival in Art: New Tendencies and

Bit International, 1961-1973 (Rosen 2011), these studies are mainly carried out as national case studies. These contributions point towards the place as vital for the production of knowledge and investigate how scientific and artistic practices are defined by, and are a part of, an active dialogue with specific geographical and historical places. ${ }^{14}$

The main argument for art historians to make inquiries about analytical methods to approach technoscience art concerns an emergent change in the relationship between art and science. Thus, they argue, in order to be able to learn from this change, it is necessary to gain a deeper understanding of the products as well as the creative processes characterizing technoscience art (see e.g. Shanken 2005). Furthermore, these scholars imply that so far the existing research, with a few exceptions, has not provided us with satisfying approaches to be able to understand and analyse technoscience art. For instance, Zwijnenberg implies that today we do not even know which discipline would be the most suited one for such a purpose (Zwijnenberg 2009, xxvi). Shanken bases a number of articles on what he considers to appear as a lack of a clearly defined method and returns to the question: What would such a method look like? It is not possible to talk about one method, he argues. Instead, Shanken emphasizes the importance of an interdisciplinary approach in order to create a 'methodological framework' from which art history would be able to look for inspiration to convey a more profound understanding of the hybrid outcomes of interdisciplinary collaborations (Shanken 2005). ${ }^{15}$ Science and technology studies (STS) have been pointed out as one of several approaches within such a framework, as well as methods from anthropology (Shanken 2007, 54).

If turning to anthropology, there are indeed several ethnographic studies of technoscience art collaborations. These are by and large conducted within particular environments such as interdisciplinary educational programmes and 'studio labs' fostering technoscience art collaborations. 
Roughly, these studies can be divided into two groups. While one is particularly concerned with questions concerning the implications of interdisciplinary collaborations on the participating actors as well as practices (Leach 2005; Fourmentraux 2006; Barry, Born and Weszkalnys 2008; Born and Barry 2010; Barry \& Born 2013; Born and Barry 2013; Krauß 2015), another part is specifically interested in methodological issues (Candy and Edmonds 2002; Steinheider and Legrady 2004; Edmonds et al 2005; Blackwell and Jefferies 2006; Edmonds 2006; Candy, Amitani and Bilda 2006; Zhang and Candy 2006; Bilda, Costello and Amitani 2006; Edmonds and Leggett 2010; Zhang 2011, Salter 2015). Whereas the art historical studies make inquiries for a methodological framework, these studies pay attention to methodological concerns on a far more practical level indeed. For instance, in a study on practice-led research, Linda Candy and Ernest Edmonds pose the rhetorical question: "What are the most effective methods for studying artists working with technologists in digital art?' (2002, 42), and answer it by arguing for 'the case study method' (Candy and Edmonds 2002, 43f). Together with the art historical research of technoscience art, these studies form a third thematic tradition.

An emergent topic within the art historical studies concerns how to understand technoscience art as being constitutive of, as well as by, the society. For instance, Catherine Mason (2008) shows how reforms within the higher educational system played a major role in fostering computer art in the UK in the late 1960's and early 1970's, and Grant D. Taylor (2014) discusses the rather poor reception of computer art during the same period of time. One reason as to why computer art remained marginalized, Taylor argues, was the military connotations surrounding the computer (Taylor 2014, 153). ${ }^{16}$ These studies imply that technoscience art is shaped by its society. Other studies investigate the impact of technoscience art on society. For instance, a number of art historians have argued for the role of early computer artists in the development of new technologies (e.g. Collins Goodyear 2004; Brown 2008; Jones 2011; Kahn 2012), ${ }^{17}$ and others argue for that science today needs the art in order to make science understandable to the public (Zwijnenberg 2009). 
The relationship between art-science and society is also paid attention to within ethnographic studies. An illuminating example, moreover one of the articles Zwijnenberg (2009) calls attention to, is the social anthropologist James Leach who suggests that art-science collaborations are an attempt to take control over an apparently 'runaway' technological development. By using the British scholarship programme New Technology Arts Fellowship (NTAF) as a case study, he investigates how interdisciplinary approaches are relevant in order to manage what has become an increased distance between science and society. Aligned with a contemporary concern, Leach argues that collaborations between artists and scientists become a form of knowledge production, or knowledge transfer, in which the artist becomes an intermediary link between science and society (Leach 2005).

However, as Georgina Born and Andrew Barry (Barry, Born and Weszkalnys 2008; Born and Barry 2010; Barry \& Born 2013; Born and Barry 2013) argue, art-science collaborations ought not to be reduced solely to a politically endorsed means to make a stronger link between science and society. Taking a wider approach towards interdisciplinarity, Born and Barry imply that interdisciplinary research, contrary to what is often claimed, is not only motivated by rationale aspects within a knowledge economy such as accountability or innovation. Certain artscience initiatives, they argue, 'are concerned less with making art or science accountable or innovative than with altering existing ways of thinking about the nature of art and science, as well as transforming the relations between artists and scientists and their objects and publics' (Born and Barry 2013, 249). The quotation illustrates what Born and Barry refer to as an 'ontological change'. This implies that art-science collaborations challenge the very notion and understanding of art and are an emergent theme within ethnographic studies on technoscience art collaborations. A similar understanding is revealed in relation to artistic research. For instance, Charlie Gere claims, 'such work is always, implicitly or explicitly, an experiment about art itself (Gere 2012, 4). And Ernest Edmonds and Mike Leggett argue that 'the use of new digital 
technology may lead to transformation of existing forms and traditional practices across disciplines' (Edmonds and Leggett 2010, 194).

It might be interesting to pay attention to the relation between an ontological change and the emergent rhetoric of newness and change in the second tradition of mapping and categorizing, presented above. Whereas the latter is defined by an underlying idea of progression, the former is rather interpreted as a mutual reconfiguration.

\section{Collaborations within the literature of technoscience art}

The most common way of writing about collaborations in the pioneer tradition is the artists, engineers and scientists who describe their experiences of the collaborations (see e.g. the contributions in Harris 1999a; Scott 2006; Scott 2010; Milosch 2013). The focus on the practical dimension of the collaboration is also anchored by illustrations. These often contain photographs showing artists, scientists and engineers while working 'in action', preferably alongside the technical or scientific equipment. Although Bijvoet $(1997,34)$ argues that the collaborations during the 1960's were not as effortless as it might have seemed, the head of the organizations has not to any larger extent discussed the difficulties faced within the collaborations in the institutional stories (cf. Bunt 2008). The individual stories do, however, pay attention to difficulties as well as how they have been coped with. For instance, the engineer Ken Knowlton pays attention to difficulties that arose as a result of lacking a common language, as he describes his collaborations with artists during the 1960s and 1970s:

The first few months of interaction with [Stan] Vanderbeek were mutually frustrating. I had hoped he would pick up my original BEFLIX language (Knowlton 1964), with all its implicit generality, and begin to do great artistic things with it; he came with great designs in his head and hoped I would program them. We needed a new way of working together - which turned out to be a new 
language that grew from one of Stan's ideas about words and letters made out of words (Knowlton 1972, 400).

Other difficulties addressed concern lack of time, communication and clash between different cultures. ${ }^{18}$ There is a prevailing apprehension among the individual stories by scientists and engineers that the collaborations have 'enriched our perspective and discussions' (Scott 2010, 97). Concerning the impact on artists, gaining new knowledge is particularly emphasized (see for instance Wilson 1999, 204-206; Sandin et al 2006; Huang 2013)

The collaboration in the second tradition is considerably less recognized, in the texts as well as in the illustrations. Mentioning the collaborating actor, en passant, as a fact in the report on artistry is a common feature, for example in formulations such as 'Artist John Dunn and Mary Anne Clark have collaborated in the creation of DNA music' (Wilson 2002, 102). And the illustrations are almost exclusively picturing art works, either separately or by installation views of exhibitions. Dietrich's report on the first decade of computer art, published in Leonardo in 1986 , is a noteworthy exception. ${ }^{19}$ Dietrich discusses why artists have chosen to collaborate with engineers and scientists and argues that the artists need the scientists and engineers in order to get access to the computers that during the era of early computer art were found at the large industrial research departments and at the university computer centres. But chiefly, they needed the programming skills of the scientists and engineers (Dietrich 1986, 162). Furthermore, Dietrich argues that this need is often most urgent during the first period of time when artists pay interest to and involve themselves in new technology (Dietrich 1986, 168). However, as Davis writes concerning the need for collaborations to create computer art during the 1960s: 'Evidence seemed to indicate that programming would soon lose its specialized vocabulary and tone, ending the era when artists were forced to instruct the machines through middlemen' (Davis 1973, 101). Before continuing, I would like to dwell upon the quotation as it reveals something about the idea of the role of the scientists and the engineers in the collaborations. That Davis 
calls them 'middlemen' with whom the artists were 'forced' to collaborate could be interpreted as a pragmatic view on the scientist and the engineer where they are depicted as a tool - or an interface - used by the artist, rather than a partner in a creative process. Indeed, both Davis and Dietrich point towards quintessential historical factors undeniably important for these kinds of collaborations to come about. Nevertheless, questions dealing with the kind of knowledge produced within the collaboration, or the implications upon the artistic as well as the scientific practice, have mainly been left unarticulated as well as unanswered.

Compared to the two former traditions, the contributions within the third tradition, nearly all with a strong recognition of STS, emphasize more strongly the collaboration as an interdisciplinary creative process. Its focus on collaborative efforts as knowledge production implies a symmetrical approach towards interdisciplinary collaborations. Hence, these collaborations are paid attention to as a mutual exchange between different disciplines and different practices in society. This might be illustrated by a tendency to use concepts containing the prefix 'co', such as 'co-evolution' (Candy, Amitani and Bilda 2006, 211; Edmonds, Weakley, Candy, Fell, Knott, Pauletto 2005, 460; Edmonds and Leggett 2010, 194; Candy and Edmonds 2011, 10), 'co-operation' (Zhang 2011, 134), 'co-produce' (Born and Barry 2013, 257) and 'coconstruction' (Orrghen 2011, 128). ${ }^{20}$

A vital question concerns the role of the place for knowledge exchange between an artistic and a scientific practice. Art historical studies on technoscience art have showed that the creation of a common language and a common place where artists, scientists and engineers are given natural opportunities to get access to each other, professionally as well as socially, are important conditions for the collaborations to take place (Jones 2008; Mason 2008; Klütsch 2012; Zschocke 2010). This is also paid attention to within ethnographic studies (Candy and Edmonds 2002; Hewett 2002; Zhang 2006; Zhang 2011). Further questions concern the creative process, the driving forces behind the collaboration, the kind of knowledge generated within these 
collaborations and its impact on the artistic as well as the scientific practice (Webster 2005; Suchman 2007; Born and Barry 2013; Orrghen 2015b).

Although these studies have indeed turned the collaboration into the object of study, it is nonetheless important to pay closer attention to the role of technoscience art collaborations in these investigations. Hence, rather than being the main question, the collaboration is examined as an example intended to illustrate larger changes in society related to interdisciplinary efforts. This is particularly captured by one of the titles: Interdisciplinarity: Reconfigurations of the Social and Natural Sciences (Barry and Born 2013), yet further illustrated by the name and disciplinary focus of the journals in which a number of the articles are published: Journal of Science Communication (Kraß 2015), Social Analysis (Leach 2005), Journal of Cultural Economy (Born and Barry 2010) and Economy and Society (Barry, Born and Weszkalnys 2008).

It is worth paying attention to that the assumption that collaborations bring about changes concerning the role of the artist as well as the art concept also has become present within the first and second traditions. Hence, there is a tendency of paying attention to an ontological change within all of the three traditions. Glauser, for instance, pays attention to that a new kind of artist is about to be fostered and implies that the educational programmes fostering collaborations might be regarded as structures transforming the art concept and the understanding of artistic work (Glauser 2010, 13f). Popper argues that the artists fostered in collective research in scientific laboratories or by interdisciplinary educational programmes, are characterized by broader technological and scientific knowledge than artists of earlier generations (Popper 2007, 6). A number of different concepts aiming at characterizing this new kind of artists appear in the literature. For example, Popper uses the concept 'technological artists' $(2007,6)$, Roger Malina 'new Leonardos' (2006, 15) and Shanken 'hybrid practitioners' ([2007] 2010, 65).

\section{Conclusion: The collaboration as the object of study}


In this article, I have described, analysed and categorized the literature on technoscience art in general and technoscience art collaborations in particular. By using technoscience as it is understood by, among others, Latour and Haraway, meaning that science and technology are inseparable in the process of knowledge making, my concern with technoscience art has been on how technoscience art is done in practice, rather than what technoscience art is. Hence, particular attention has been paid to technoscience art collaborations.

I have categorized the literature into three thematic traditions. Whereas the first one consists of pioneer stories, the second one maps and categorizes technoscience art and the third one problematizes and contextualizes technoscience art. Since earlier research on technoscience art collaborations primarily consists of art historical and anthropological and ethnographic studies, I have discussed the relation between these approaches, and have thereby intended to provide a connection between them.

Art historical studies on technoscience art have paid attention to that technoscience art has been disregarded or misinterpreted within art history. Hence, the overall aim of these studies has been to open up art history to also include technoscience art. Anthropological and ethnographic studies on technoscience art, on the other hand, approach technoscience art collaborations as a means to understand larger changes in society related to interdisciplinarity. Thus, whereas art historical studies could be said to be concerned with issues concerning art history as a discipline, anthropological and ethnographic studies are more concerned with challenges faced by interdisciplinarity. A common denominator between these approaches is, however, that art historical as well as anthropological and ethnographic studies pay attention to that these kinds of interdisciplinary collaborations challenge the notion of art and art making, and hence bring about ontological changes.

This article's focus to put the literature on technoscience art from art history, STS and anthropology into dialogue has, nevertheless, meant that other aspects of technoscience art are excluded. As I have showed in this article, different approaches call for different methods, 
and hence provide different answers. Given that some of the literature that in this paper is categorized as ethnographic studies (e.g. Candy and Edmonds 2002; Candy and Edmonds 2011; Salter 2015), pioneer studies (e.g. Niemeyer 2005; Hostettler 2010), or used for mapping and categorizing the field (e.g. Kac 2007) could also be referred to as artistic research, sheds light upon one of the difficulties faced by conducting historiographical analyses. This further raises questions concerning the role of artistic research in the understanding of technoscience art. Could questions on collaborations within technoscience art also be studied through artistic research? A number of examples, all with a strong recognition of the contributions of STS, technoscience, feminist technoscience, history of science and technology, explore technoscience art collaborations in yet another way than is captured by the thematic traditions in this article (da Costa and Philips 2008; Beloff, Berger and Haapoja 2011; Prophet and Hamlett 2000; Prophet and Wakeford 2010; Smite, Kluitenberg and Smits 2013; Smite, Medosch and Smits 2014; Smite, Smits and Medosch 2016).

One overall question that is missing in the literature reviewed in this article, thus neither examined in the art historical nor in the anthropological or ethnographic writings, concerns the role of technoscience art in society. Artistic research might contribute to this field. There is, however, yet another body of literature, also from art practice and not either treated in this overview, which is deeply concerned with the role of technoscience art in society. This kind of works has resurrected the term "avant-garde" and argues that the idea of the avant-garde as resistance has an increased importance in the current political climate (Léger 2014; Stimson and Sholette 2007; Ziarek 2004). One example is the work by the Critical Art Ensemble taking a political stance in which they argue that the state of affairs concerning, among other things human rights and environment requires technoscience art to use the force of art to affect perspectives and power relations in society (Critical Art Ensemble 1994, 1996, 2001, 2008; Sholette 2005). 
By saying this, I would like to emphasize the diversity of the literature on technoscience art, as well as the understanding of technoscience art collaborations as an interdisciplinary effort. This does, however, not imply that there is a dichotomy between interdisciplinarity and disciplinarity. As is argued by Thomas Osborne: 'Far from being opposed to disciplinarity, interdisciplinarity assumes a certain consciousness of disciplinarity as a condition for its accomplishment' (2013, 82). Art historical and anthropological and ethnographical approaches as well as artistic research and art practice are thus all important contributions in order to gain a deeper understanding of technoscience art collaborations, nonetheless to write their historiography. ${ }^{21}$

Acknowledgements

I wish to acknowledge the valuable support by Per Lundin, the research seminar at the Department of Art History at Uppsala University and the Digital Creativity anonymous referees for their valuable comments to improve the original draft of this article.

Disclosure statement

No potential conflict of interest was reported by the author.

Funding

This article was written as a part of the research project 'The Art of Co-Production:

Collaborations Between Artists, Scientists and Engineers, Sweden 1967-2009', funded by the Swedish Research Council (Dnr 421-2010-1531).

Notes on contributor 
Anna Orrghen is a researcher and senior lecturer at the Department of Art History at Uppsala

University, Sweden. She holds a PhD in media and communication studies from Stockholm

University and has published on art and media, history of computer art, as well as art, science and technology.

\section{References}

Allen, Rebecca. 2005. “The Emergence Project: The Bush Soul.” Leonardo 38 (4): 314.

Ascott, Roy. 2011. "Preface". In Explorations in Art and Technology, edited by Linda Candy and Ernest Edmonds, v-vi. New York: Springer.

Barry, Andrew, Georgina Born and Gisa Weszkalnys. 2008. "Logics of Interdisciplinarity.” Economy and Society 37 (1): 20-49.

Barry, Andrew and Georgina Born. 2013. "Interdisciplinarity: Reconfigurations of the Social and Natural Sciences." In Interdisciplinarity: Reconfigurations of the Social and Natural Sciences, edited by Andrew Barry and Georgina Born, 1-56. Oxfordshire: Routledge.

Belfiore, Eleonora. 2004. “Auditing Culture: The Subsidised Cultural Sector in the New Public Management." International Journal of Cultural Policy 10 (2): 183-202.

Beloff, Laura, Erich Berger and Terike Haapoja. 2011. Field Notes: From Landscape to Laboratory. Helsinki: Finnish Society of Bioart.

Bertók, Imrich and Jozef Jankovic. 1986. “A Collaborative Investigation of the Line: Interactive Computer-Aided Drawings." Leonardo 19 (1): 27-30.

Biggs, Michael and Henrik Karlsson, eds. 2011. The Routledge Companion to Research in the Arts. New York and Abingdon: Routledge.

Bijvoet, Marga. 1997. Art as Inquiry: Toward New Collaborations Between Art, Science, and Technology.

New York: Peter Lang. 
Bilda, Zafer, Brigid Costello and S. Amitani. 2006. "Collaborative Analysis Framework for Evaluating Interactive Art Experience." CoDesign: International Journal of CoCreation in Design and the Arts 2 (4): 225-238.

Blackwell, T. and J. Jefferies. 2006. "Collaboration: A Personal Report.” CoDesign: International Journal of CoCreation in Design and the Arts 2 (4): 259-263.

Born, Georgina and Andrew Barry. 2010. “Art-Science.” Journal of Cultural Economy 3 (1): 103-119. Born, Georgina and Andrew Barry. 2013. “Art-Science: From Public Understanding to Public Experiment." In Interdisciplinarity: Reconfigurations of the Social and Natural Sciences, edited by Andrew Barry and Georgina Born, 247-272. Oxfordshire: Routledge. Broeckmann, Andreas and Gunalan Nadarajan, eds. 2008. Place Studies in Art, Media, Science and Technology: Historical Investigations on the Sites and the Migration of Knowledge. Weimar: VDG.

Brown, Judy and Steve Cunningham. 2007. "A History of ACM SIGGRAPH." Communications of the ACM 50 (5): 54-61.

Brown, Paul, Charlie Gere, Nicholas Lambert and Catherine Mason, eds. 2008. White Heat Cold Logic: British Computer Art 1960-1980. Cambridge, MA: MIT Press.

Brown, Paul. 2008. 'From Systems Art to Artificial Life: Early Generative Art at the Slade School of Fine Art". In White Heat Cold Logic: British Computer Art 1960-1980, edited by Paul Brown, Charlie Gere, Nicholas Lambert and Catherine Mason, 275-289. Cambridge, MA: MIT Press.

Bunt, Stuart. 2008. "The Role of the Scientist and Science in Bio-art." In Art in the Biotech Era, edited by Melentine Pandilovski, 62-67. Adelaide: Experimental Art Foundation. Candy, Linda and Ernest Edmonds. 2002. Explorations in Art and Technology, New York: Springer. Candy, Linda, S Amitani and Z Bilda. 2006. "Practice-led Strategies for Interactive Art Research." CoDesign: International Journal of CoCreation in Design and the Arts 2 (4): 209-223. 
Candy, Linda and Ernest Edmonds. 2011. Interacting: Art, Research and the Creative Practitioner, Faringdon: Libri Publishing.

Catts, Oron and Stuart Bunt. 2001. "SymbioticA, The Art and Science Collaborative Research Laboratory." In Takeover: Wer macht die Kunst von morgen: Who's Doing the Art of Tomorrow, Ars Electronica 2001, edited by Gerfried Stocker and Christine Schöpf, 132-135. Wien: Springer.

Century, Michael. 1999. Pathways to Innovation in Digital Culture. Centre for Research on Canadian Cultural Industries and Institutions/Next Century Consultants.

Century, Michael. 2015. “'Pathways to Innovation in Digital Culture’ Revisited”, unpublished paper presented at Re-create 2015: The 10th Anniversary and Sixth International Conference on the Histories of Media, Art, Science and Technology, Montréal, Canada, November 5-8. Accessed, October 14, 2016. http://pl02.donauuni.ac.at/jspui/handle/10002/687.

Chan, Janet, Roanna Gonsalves and Noreen Metcalfe. 2011. "Bridging the Two Cultures: The Fragility of Interdisciplinary Creative Collaboration.” In Collective Creativity: Collaborative Work in the Sciences, Literature and the Arts, edited by Gerhard Fischer and Florian Vassen, 156-176. Amsterdam: Rodopi.

Collins Goodyear, Anne. 2004. "Gyorgy Kepes, Billy Klüver, and American Art of the 1960s:

Defining Attitudes Toward Science and Technology”. Science in Context 17 (4): 611635.

Collins Goodyear, Anne. 2008. "From Technophilia to Technophobia: The Impact of the Vietnam War on the Reception of "Art and Technology"." Leonardo 41 (2): 169173.

Critical Art Ensemble. 1994. The Electronic Disturbance. New York: Autonomedia. Critical Art Ensemble. 1996. Electronic Civil Disobedience and Other Unpopular Ideas. New York: Autonomedia. 
Critical Art Ensemble. 2001. Digital Resistance: Explorations in Tactical Media. New York: Autonomedia.

Critical Art Ensemble. 2008. “The Spectacle of Public Health Under the Sign of Bioterror.” In Art in the Biotech Era, edited by Melentine Pandilovski, 34-40. Adelaide: Experimental Art Foundation.

da Costa, Beatriz and Kavita Philips, eds. 2008. Tactical Biopolitics: Art, Activism, and Technoscience. Cambridge, MA: The MIT Press.

Cubitt, Sean, Paul Thomas, eds. 2013. Relive: Media Art Histories. Cambridge, MA: MIT Press. Davis, Douglas. 1973. Art and the Future: A history/Prophecy of the Collaboration Between Science, Technology and Art. New York: Praeger.

Demain, Erik D., Martin L. Demain and A. Laurie Palmer. 2006. “The Helium Stockpile: A Collaboration in Mathematical Folding Sculpture.” Leonardo 39 (3): 233-235.

Dietrich, Frank. 1986. "Visual Intelligence: The First Decade of Computer Art.” Leonardo 19 (2): 159-169.

EAT [1966] 2003. “9 Evenings: Theatre and Engineering”. Program. In The New Media Reader, edited by Noah Wardrip-Fruin and Nick Montfort, 214-221. Cambridge, Massachusetts, London, England: MIT Press.

EAT [1967] 2003. Press release. In The New Media Reader, edited by Noah Wardrip-Fruin and Nick Montfort, 222. Cambridge, Massachusetts, London, England: MIT Press. Edmonds, Ernest, Alastair Weakly, Linda Candy, Mark Fell, Roger Knott and Sandra Pauletto. 2005. "The Studio as Laboratory: Combining Creative Practice and Digital Technology Research.” International Journal of Human-Computer Studies 63 (4-5): 452481.

Edmonds, Ernest. 2006. "New Directions in Interactive Art Collaboration.” CoDesign: International Journal of CoCreation in Design and the Arts 2 (4): 191-194. 
Edmonds, Ernest and Mike Leggett. 2010. “How Artists Fit into Research Processes.” Leonardo 43 (2): 194-195.

Edwards, David. 2008. Artscience: Creativity in the Post-Google Generation. Cambridge, Massachusetts and London, England: Harvard University Press.

Edwards, David. 2010. The Lab: Creativity and Culture. Cambridge, Massachusetts and London, England: Harvard University Press.

Fernández, María. 2008. “Gordon Pask: Cybernetic Polymath”, Leonardo 41 (2): 162-168.

Fourmentraux, Jean-Paul. 2006. "Internet Artworks, Artists and Computer Programmers: Sharing the Creative Process." Leonardo 39 (1): 44-50.

Franke, Herbert W. 1971a. Computer Graphics: Computer Art. London: Phaidon.

Franke, Herbert W. 1971b. “Computers and Visual Art”. Leonardo 4 (4): 331-338.

Frieling, Rudolf, and Dieter Daniels. 1999. Medien Kunst Interaktion. Die 80:er und 90er Jahre in Deutschland. Wien: Springer.

Fritz, Darko. 2008. “Vladimir Bonacic: Computer-Generated Works Made Within Zagreb’s New Tendencies Network (1961-1973)", Leonardo 41 (2):175-183.

Fritz, Darko. 2011. Mapping the Beginnings of Computer-generated Art in the Netherlands. http://darkofritz.net/text/DARKO_FRITZ_NL_COMP_ART_n.pdf (Accessed October 7, 2015).

Gerber, Beat. 2006. "Science in Trouble? Art Brings Hope." In Artists-in-Labs: Processes of Inquiry, edited by Jill Scott, 47-49. Wien and New York: Springer.

Gere, Charlie. 2010. "Research as Art". In Art Practice in a Digital Culture, edited by Hazel Gardiner and Charlie Gere, 1-7. Farnham and Burlington: Ashgate.

Gere, Charlie. 2012. "Minicomputer Experimentalism in the United Kingdom from the 1950s to 1980s". In Mainframe Experimentalism: Early Computing and the Foundations of Digital Arts, edited by Hannah B. Higgins and Douglas Kahn, 112-127. Berkeley, Los Angeles and London: University of California Press. 
Glauser, Andrea. 2010. “Formative Encounters: Laboratory Life and Artistic Practice.” In Artistsin-Labs: Networking in the Margins, edited by Jill Scott, 12-22. Wien and New York: Springer.

Grau, Oliver, ed. 2007a. Media Art Histories. Cambridge, Massachusetts and London, England: The MIT Press.

Grau, Oliver. 2007b. “Introduction”. In Media Art Histories. Cambridge, Massachusetts and London, edited by Oliver Grau, 1-14. England: The MIT Press.

Green, Rachel. 2000. “Web Work: A History of Internet Art”, ArtForum 38: 162-167, 190. Haraway, Donna J.1997.Modest_Witness@Second_Millenium.FemaleMan (C_Meets_OncoMouse ${ }^{\mathrm{TM}}$ : Feminism and Technoscience. New York and London: Routledge.

Harris, Craig, ed. 1999a. Art and Innovation: The Xerox Parc Artist-in-Residence Program. Cambridge, MA and London: The MIT Press.

Harris, Craig. 1999b. “The Xerox Palo Alto Research Center Artist-in-Residence Program Landscape." In Art and Innovation: The Xerox Artist-in-Residence Program, edited by Craig Harris, 2-11. Cambridge, Massachusetts and London, England: The MIT Press.

Hedlin Hayden, Malin. 2015. Video Art Historicized: Traditions and Negotiations. Farnham: Ashgate. Henderson, Linda Dalrymple. 2004. “Editor's Introduction: I. Writing Modern Art and Science An Overview; II. Cubism, Futurism, and Ether Physics in the Early Twentieth Century." Science in Context 17 (4): 423-466.

Hewett, Thomas. 2002. “An Observer's Reflections: The Artist Considered as Expert”. In Explorations in Art and Technology, edited by Linda Candy and Ernest Edmonds, 137144. New York: Springer.

Higgins, Hannah B. and Douglas Kahn, eds. 2012. Mainframe Experimentalism: Early Computing and the Foundations of Digital Arts. Berkeley: University of California Press.

Hostettler, Sylvia. 2010. “Light Reactions: Dimensions of Apparent Invisibility”. In Artists-in- 
Labs: Networking in the Margins, edited by Jill Scott, 132-137. Wien and New York: Springer.

Huang, Shih Chieh. 2013. "The Influence and Inspiration from Taking Part in the Smithsonian Artist Research Fellowship Program.” In Analyzing Art and Aesthetics, edited by Anne Collins Goodyear and Margaret A. Weitekamp, 268-277. Washington, D.C.: Smithsonian Institution Scholarly Press.

Jasanoff, Sheila. 2004. States of Knowledge: The Co-Production of Science and the Social Order. London: Routledge.

Jones, Stephen. 2008. 'The Confluence of Computing and Fine Arts at the University of Sidney, 1968-1975.” In Place Studies in Art, Media, Science and Technology: Historical Investigations on the Sites and the Migration of Knowledge, edited by Andreas Broeckmann and Gunalan Nadarajan, 55-74. Weimar: VDG.

Jones, Stephen. 2011. Synthetics: Aspects of Art and Technology in Australia, 1956-1975. Cambridge, MA: MIT Press.

Kac, Eduardo, ed. 2007. Signs of Life: Bio Art and Beyond. Cambridge, MA: The MIT Press. Kahn, Douglas. 2012. “James Tenney at Bell Labs”. In Mainframe Experimentalism: Early Computing and the Foundations of Digital Arts, edited by Hannah B. Higgins and Douglas Kahn, 131-146. Berkeley, Los Angeles and London: University of California Press.

Klütsch, Christoph. 2012. "Information aesthetics and the Stuttgart school”. In Mainframe Experimentalism: Early Computing and the Foundations of Digital Arts, edited by Hannah B. Higgins and Douglas Kahn, 65-89. Berkeley, Los Angeles and London: University of California Press.

Klüver, Billy, and Rauschenberg, Robert. [1967] 2009. "The Purpose of Experiments in Art and Technology." In Art and Electronic Media, edited by Edward Shanken, 267-268. London: Phaidon. 
Klüver, Billy. [1967] 2009. “Theater and Engineering: An Experiment; Notes by an Engineer”. In Art and Electronic Media, edited by Edward Shanken, 266-267. London: Phaidon. Klüver, Billy. [1972] 2003. “The Pavilion”. In The New Media Reader, edited by Noah WardripFruin and Nick Montfort, 223-226. Cambridge, Massachusetts, London, England: MIT Press.

Knowlton, Ken. 1972. “Collaborations with Artists — A Programmer's Reflections.” In Graphic Languages: Proceedings of the IFIP Working Conference on Graphic Languages, edited by. F. Nake and A. Rosenfeld, 399-418. Amsterdam and London: NorthHolland Publishing Company.

Krauß, Werner. 2015. "Linking Sediment and Sentiment: On Observing a Sci-Art Project." Journal of Science Communication 14 (01): C04, 1-7.

Latour, Bruno. [1987] 1999. Science in Action: How to Follow Scientists and Engineers Through Society. Cambridge, Massachusetts: Harvard University Press.

Latour, Bruno. 1993. We Have Never Been Modern. Translated by Catherine Porter. Cambridge, Massachusetts: Harvard University Press.

Leach, James. 2005. “'Being in Between’ Art-Science Collaborations and a Technological Culture." Social Analysis 49 (1): 141-160.

Léger, Marc James, ed. 2014. The Idea of the Avant Garde: And What it Means Today. Manchester: Manchester University Press.

Malina, Roger. 2006. "Welcoming Uncertainty: The Strong Case for Coupling Art to Science and Technology.” In Artists-in-Labs: Processes of Inquiry, edited by Jill Scott, 15-23. Wien and New York: Springer.

Manovich, Lev. 2003. "New Media from Borges to HTML”. In The New Media Reader, edited by Noah Wardrip-Fruin and Nick Montfort, 13-25. Cambridge, Massachusetts, London, England: MIT Press. 
Mason, Catherine. 2008. A Computer in the Art Room: The Origins of British Computer Arts 19501980. Hindringham: JJG.

Miller, Arthur I. 2014. Colliding Worlds: How Cutting-Edge Science is Redefining Contemporary Art. New York and London: W. W. Norton \& Company.

Milosch, Jane. 2013. “Contemporary Art informed by Science: The Smithsonian Artist Research Fellowship." In Analyring Art and Aesthetics, edited by Anne Collins Goodyear and Margaret A. Weitekamp, 260-267. Washington, D.C.: Smithsonian Institution Scholarly Press.

Misa, Thomas J. 2007. “Understanding 'How Computing Has Changed the World”, IEEE Annals of the History of Computing 29 (4): 52-63.

Mitchell, William J., Alan S. Inouye and Marjory S. Blumenthal, eds. 2003. Beyond Productivity: Information, Technology, Innovation, and Creativity. Committee on Information Technology and Creativity; Computer Science and Telecommunications Board; Division of Engineering and Physical Sciences; National Research Council. Moraga, Eva. 2008. “The Computation Center at Madrid University, 1966-1973: An Example of True Interaction between Art, Science, and Technology." In Place Studies in Art, Media, Science and Technology: Historical Investigations on the Sites and the Migration of Knowledge, edited By Andreas Broeckmann and Gunalan Nadarajan, 47-53. Weimar: VDG.

Moser, Mary Anne, and Douglas MacLeod, eds. 1996. Immersed in Technology: Art and Virtual Environments. Cambridge, MA and London, UK: The MIT Press.

Naimark, Michael. [2003] 2004. Truth, Beauty, Freedom, and Money: Technology-Based Art and the Dynamics of Sustainability: A report for Leonardo Journal supported by the Rockefeller Foundation. www.naimark.net (Accessed October 10, 2016).

Nechvatal, Joseph. 2004. “Origins of Virtualism: An Interview with Frank Popper Conducted by Joseph Nechvatal.” CAA Art Journal 63 (1): 62-77. 
Niemeyer, Greg. 2005. “PING: Poetic Charge and Technical Implementation.” Leonardo 38 (4): 312-313.

Orrghen, Anna. 2011. "Collaborations between Engineers and Artists in the Making of Computer Art in Sweden 1967-1986." In History of Nordic Computing 3: Third IFIP WG9.7 Conference, HiNC3, Stockholm, Sweden, October 18-20, 2010: Revised Selected Papers, edited by John Impagliazzo, Per Lundin and Benkt Wangler, 127-136. Heidelberg: Springer Verlag.

Orrghen, Anna. 2015a. "ICT in art in Sweden, 1996-2014: Tool, Medium and Theme.” In History of Nordic Computing 4, 4th IFIP WG 9.7 Conference, HiNC 4, Copenhagen, Denmark, August 13-15, 2014, Revised Selected Papers, edited by Christian Gram, Per Rasmussen and Søren Duus Østergaard, 78-89. Heidelberg: Springer Verlag.

Orrghen, Anna. 2015b. "Driven by Visualization: Sten Kallin’s Collaborations with Astrid Sampe, Sture Johannesson, and Mats Amundin as Explorations of Computer Technology." Konsthistorisk tidskrift/Journal of Art History 84 (2): 93-107.

Osborne, Thomas. 2013. "Inter that Discipline!” In Interdisciplinarity: Reconfigurations of the Social and Natural Sciences, edited by Andrew Barry and Georgina Born, 82-98. Oxfordshire: Routledge.

Oudshoorn, Nelly and Trevor Pinch. 2003. How Users Matter. Cambridge, MA: MIT Press. Paul, Christiane. [2003] 2008. Digital Art. London: Thames \& Hudson.

Penny, Simon. 2010. “Twenty Years of Artificial Life Art.” Digital Creativity 21 (3): 197-204.

Penny, Simon. 2013. "Art and Robotics: Sixty Years of Situated Machines.” AI \& Society 28 (2): 147-156.

Plautz, Dana. 2005. “New Ideas Emerge When Collaboration Occurs.” Leonardo 38(4): 302-309. Popper, Frank. 1968. Origins and Development of Kinetic Art. Translated by Stephen Bann. London: Studio Vista.

Popper, Frank. 1987. “Technoscience Art: The Next Step.” Leonardo 20 (4): 301-303. 
Popper, Frank. 1993. Art of the Electronic Age. London: Thames \& Hudson.

Popper, Frank. 2007. From Technological to Virtual Art. Cambridge, MA: MIT Press.

Prophet, Jane and Sian Hamlett. 2000. “Sordid Sites: The Internal Organs of a Cyborg." In Digital Desires: Language, Identity and New Technologies, edited by Cutting Edge, The Women's Research Group, 25-33. London: Tauris.

Prophet, Jane and Nina Wakeford. 2010. “A Conversation About Models and Prototypes.” In Art Practice in a Digital Culture, edited by Hazel Gardiner and Charlie Gere, 43-59. Farnham: Ashgate.

Reichardt, Jasia. 1969. Cybernetic Serendipity: The Computer and the Arts. New York: Studio International.

Reichle, Ingeborg. 2009. Art in the Age of Technoscience: Genetic Engineering, Robotics, and Artificial Life in Contemporary Art. Translated by Gloria Custance. Wien and New York: Springer. Rosen, Margit, ed. 2011. A Little Known Story About a Movement, a Magazine, and the Computer's Arrival in Art: New Tendencies and Bit International, 1961-1973. Karlsruhe: ZKM/Center for Art and Media.

Salter, Chris. 2015. Alien Agency: Experimental Encounters with Art in the Making. Cambridge, MA and London, UK: The MIT Press.

Sandin, Daniel J., Tom DeFanti, Louis H. Kauffman and Yvonne Spielmann. 2006. "The Artist and the Scientific Research Environment.” Leonardo 39 (3): 219-221.

Schlick, Tamar. 2005. "The Critical Collaboration Between Art and Science: An Experiment on a Bird in the Air Pump and the Ramifications of Genomics for society." Leonardo 38 (4): 323-329.

Schöpf, Christine. 2004. “The making of ...”. In Ars Electronica 1979-2004: The Network for Art, Technology and Society: The First 25 Years, edited by Hannes Leopoldseder, Christine Schöpf and Gerfried Stocker, 18-24. Ostfildern-Ruit: Hatje Cantz Verlag.

Scott, Jill, ed. 2006. Artists-in-Labs: Processes of Inquiry. Wien and New York: Springer. 
Scott, Jill, ed. 2010. Artists-in-Labs: Networking in the Margins. Wien and New York: Springer.

Seaman, Bill. 2005. “The Hybrid Invention Generator.” Leonardo 38 (4): 315.

Shanken, Edward A. 2005. "Artist in Industry and the Academy: Collaborative Research, Interdisciplinary Scholarship and the Creation and Interpretation of Hybrid Forms." Leonardo 38 (5): 415-418.

Shanken, Edward A. 2007. "Historicizing Art and Technology: Forging a Method and Firing a Canon.” In Media Art Histories, edited by Oliver Grau, 43-70. Cambridge, Massachusetts and London, England: The MIT Press.

Shanken, Edward A. 2008. “The Reception and Rejection of Art and Technology: Exclusions and Revulsions". Leonardo 41 (2): 160-161.

Shanken, Edward A. 2009. Art and Electronic Media. London: Phaidon.

Shanken, Edward A. 2010. "The History and Future of the Lab: Collaborative Research at the Intersections of Art, Science and Technology.” In The Future of the Lab 2010, edited by Clare Butcher and Angela Plohman, 21-33. Eindhoven: Baltan Laboratories.

Shapin, Steven. 2008. The Scientific Life: A Moral History of a Late Modern Vocation. Chicago and London: The University of Chicago Press.

Sholette, Gregory. 2005. "Disciplining the Avant-Garde: The United States versus The Critical Art Ensemble.” Circa No 112: 50-59.

Smite, Rasa, Eric Kluitenberg and Raitis Smits, eds. 2013. “Techno-Ecologies.” Acoustic Space No. 11.

Smite, Rasa, Armin Medosch and Raitis Smits, eds. 2014. “Techno-Ecologies II: Media Art Histories: ReNew.” Acoustic Space No. 12.

Smite, Rasa, Raitis Smits and Armin Medosch, eds. 2016. "Open Fields: Art and Science Research Practices in the Network Society." Acoustic Space No. 15.

Sorensen, Vibeke. 2005. “Global Visual Music Jam Project.” Leonardo 38 (4): 316. 
Steinheider, Brigitte, and George Legrady. 2004. "Interdisciplinary Collaboration in Digital Media Arts: A Psychological Perspective on the Production Process." Leonardo 37 (4): 315321.

Stettler, René. 2006. “Perception-Translation-Transformation.” In Artists-in-Labs: Processes of Inquiry, edited by Jill Scott, 36-42. Wien and New York: Springer.

Stiles, Kristine and Peter Selz. 1996. Theories and Documents of Contemporary Art: A Sourcebook of Artists' Writings. Berkeley: University of California Press.

Stimson, Blake and Gregory Sholette. 2007. "Introduction: Periodizing Collectivism.” In Collectivism After Modernism: The Art of Social Imagination after 1945, edited by Blake Stimson and Gregory Sholette, 1-15. Minneapolis and London: University of Minnesota Press.

Stonyer, Andrew, Ken Ford, Malcom Hughes and Roger Linford. 1986. "Solar-Powered Kinetic Sculpture: A Collaborative Educational Experiment.” Leonardo 19 (1): 35-38.

Suchman, Lucy A. 2007. Human-Machine Reconfigurations: Plans and Situated Actions, $2^{\text {nd }}$ Edition. Cambridge: Cambridge University Press.

Taylor, Grant D. 2014. When the Macbine Made Art: The Troubled History of Computer Art. New York: Bloomsbury Academic.

Turney, Jon, ed. 2006. Engaging Science: Thoughts, Deeds, Analysis, and Action. London: The Wellcome Trust.

Vesna, Victoria and James K. Gimzewski. 2005. "NANO: An Exhibition of Scale and Senses." Leonardo 38 (4): 110-111.

Wands, Bruce. 2006. Art of the Digital Age. London: Thames and Hudson.

Wardrip-Fruin, Noah and Nick Montfort, eds. 2003. The New Media Reader. Cambridge, Massachusetts, London, England: MIT Press.

Webster, Stephen. 2005. “Art and Science Collaborations in the United Kingdom.” Nature Reviews Immunology 5 (12): 965-969. 
Webster, Stephen. 2006. “Art, Science, and the Public.” In Engaging Science: Thoughts, Deeds, Analysis, and Action, edited by Jon Turney, 74-79. London: The Wellcome Trust.

Wilson, Stephen. 1999. "Reflections on PAIR.” In Art and Innovation: The Xerox Artist-in-Residence Program, edited by Craig Harris, 186-208. Cambridge, Massachusetts and London, England: The MIT Press.

Wilson, Stephen. 2002. Information Art: Intersection of Art, Science, and Technology. Cambridge, MA: The MIT Press.

Wilson, Stephen. 2010. Art + Science Now: How Scientific Research and Technological Innovation are Becoming Key to 21st-Century Aestetbics. London: Thames \& Hudson.

Zhang, Yun and Linda Candy. 2006. "Investigating Collaboration in Art and Technology." CoDesign: International Journal of CoCreation in Design and the Arts 2 (4): 239-248.

Zhang, Yun. 2011. "Investigating Collaboration in Art and Technology.” In Interacting: Art, Research and the Creative Practitioner, edited by Linda Candy and Ernest Edmonds, 122-135. Faringdon: Libri Publishing.

Ziarek, Krzysztof. 2004. The Force of Art. Stanford: Stanford University Press.

Zschocke, Nina. 2010. “Art and Science Research Teams? Some Arguments in Favour of a Culture of Dissent." In Artists-in-Labs: Networking in the Margins, edited by Jill Scott, 68-81. Wien and New York: Springer

Zwijnenberg, Robert. 2009. “Art, the Life Sciences, and the Humanities: In Search of a Relationship." In Art in the Age of Technoscience. Genetic Engineering, Robotics, and Artificial Life in Contemporary Art, Ingeborg Reichle, xiv-xxix. Wien and New York: Springer.

\footnotetext{
${ }^{1}$ Reichle pays particular attention to the contributions made by the scholars Bruno Latour and Donna J. Haraway.
} 
${ }^{2}$ Although Reichle (2009), on one hand, pays attention to Popper's introduction of the term technoscience art and uses the same time frame as Popper does, and, on the other hand, builds her understanding of the concept of technoscience mainly on Latour's contribution, her study does not address the differences in the understanding of the concept of technoscience as it is expressed by Popper and Latour.

${ }^{3}$ The literature on technoscience art contains a number of concepts for describing different aspects of technology and science in contemporary art such as 'bio art', 'virtual art' and 'new media art'. Christiane Paul has paid attention to the terminology for technological art forms as 'extremely fluid' ([2003] 2008, 7) and subject to several name changes.

${ }^{4}$ Shanken pays attention to Henderson (2004) as an exception.

${ }^{5}$ On the part of the universities for the development of early computer art in Australia (see Jones 2011), in Spain (see Moraga 2008), in Germany (see Klütsch 2012), in Sweden (see Orrghen 2011) and in the Netherlands (see Fritz 2011).

${ }^{6}$ Put together, Century (1999), Harris (1999b), Shanken (2005), Zwijnenberg (2009), Naimark ([2003] 2004), Born and Barry (2013) and Miller (2014) provide a thorough review of the institutional development of efforts aimed at supporting collaborations between artists, scientists and engineers from the 1960s through the twenty-first century.

${ }^{7}$ For an updated analysis of the development of the studio laboratory, see Century (2015).

${ }^{8}$ The categorization of these traditions shows a striking resemblance with how the history of computing (Misa 2007) and the history of video art (Hedlin Hayden 2015) have been categorized.

${ }^{9}$ See also Reichardt (1969), and interviews, manifestos, excerpts from exhibition catalogues, articles and other documents republished in publications mainly belonging to the second tradition in this article (e.g. Davis 1973; Stiles and Selz 1996; Wardrip-Fruin and Montfort 2003; Shanken 2009).

${ }^{10}$ Further examples document the activities at the Banff Centre for the Arts (Moser and MacLeod 1996), ZKM (Frieling and Daniels 1999), the art and science collaborative research laboratory SymbioticA (Catts and Bunt 2001), the scholar programme founded by Intel Art and Innovation Committee (IAEC) (Plautz 2005), the Swiss exchange program Artist-in-Labs (Scott 2006, Scott 2010), the art-science center Le Laboratoire in Paris (Edwards 2008, 2010) and the Smithsonian Artist Research Fellowship (SARF) (Milosch 2013).

${ }^{11}$ On the relation between art and the IT industry, see Mitchell, Inouye and Blumenthal (2003).

${ }^{12}$ See, for example, Stonyer et al. (1986); Vesna and Gimzewski (2005); Niemeyer (2005); Seaman (2005); Sorensen (2005); Demain, Demain and Palmer (2006). According to Bijvoet (1997, 78), Leonardo's contributors during its first seven or eight years were either practising artists describing their own works or scientists and engineers contributing 
with general or theoretical articles, whereas there were hardly any contributions made by art historians or art theoreticians. Shanken $(2007,46)$, on the other hand, means that it took until the mid-1990s before art historians and art theoreticians started to contribute to Leonardo.

${ }^{13}$ For example, Klüver and Rauschenberg ([1967] 2009]. An extract from the article is republished in Shanken (2009, 267-268).

${ }^{14}$ See also Broeckmann and Nadarajan (2008); Higgins and Kahn (2012).

${ }^{15}$ The first time the question appears is in the article 'Artist in Industry and the Academy: Collaborative Research, Interdisciplinary Scholarship and the Creation and Interpretation of Hybrid Forms' published in Leonardo (2005). The same article also appears as a contribution in Scott (2006). Thereafter, the question reappears in Shanken (2007) and Shanken (2010).

${ }^{16}$ On the impact of the Vietnam War on the reception of art and technology, see Collins Goodyear (2008).

${ }^{17}$ Douglas Kahn (2012) pays attention to the composer James Tenney as an artist in residence at Bell Telephone Laboratories, and argues for Tenney's contribution to engineering; Paul Brown (2008) claims that the early generative art at the Slade School of Fine Art contributed to the scientific development of computers; Stephen Jones (2011, especially chapters 1 and 4) argues for the role of artists in the development of new technologies in Australia; and Anne Collins Goodyear $(2004,628)$ argues that many collaborations supported by EAT led to engineering breakthrough and innovations.

${ }^{18}$ On these issues, see for example Scott (2010, 96-123); Stettler (2006, 37); Zschocke (2010); Seaman (2005); Steinheider and Legrady (2004).

${ }^{19}$ Also Shanken (2009) and Wilson (2002) are using headlines underneath which they present collaborations.

${ }^{20}$ On 'co-production' within STS, see for instance Jasanoff (2004); on 'co-construction', see Oudshoorn and Pinch (2003).

${ }^{21}$ It might be interesting to note that the theme of the Media Art Histories conference taking place in 2015 was 'Recreate: Theories, Methods and Practices of Research-creation in the Histories of Media Art, Science and Technology'; that it partly took place at a venue for conducting research-based creative practice in technoscience art, Hexagram; and that the anthropologist Georgina Born gave one of the keynote speeches. 